\title{
Community Resource Uses and Ethiopian Wolf Conservation in Mount Abune Yosef
}

\author{
Girma Eshete $^{1,2,3} \cdot$ Girmay Tesfay $^{4} \cdot$ Hans Bauer $^{5} \cdot$ Zelealem Tefera Ashenafi $^{6}$. \\ Hans de Iongh ${ }^{1} \cdot$ Jorgelina Marino $^{3,5}$
}

Received: 4 December 2014/Accepted: 29 April 2015/Published online: 14 May 2015

(C) The Author(s) 2015. This article is published with open access at Springerlink.com

\begin{abstract}
People who perceive economic benefits and enjoy unrestricted access to natural resources tend to support ecosystem conservation efforts. Our study explores whether this remains true in remnant patches of Afroalpine ecosystem in North Ethiopia, where communal land provides valuable natural resources for the local communities and also sustain small populations of the endangered Ethiopian wolf (Canis simensis). Questionnaires were designed to assess ecological and socio-economic characteristics of the livelihoods of the Amhara people living in Mount Abune Yosef and their attitudes toward Afroalpine and Ethiopian wolf conservation. Of the 120 households interviewed, selected randomly from across eight villages, $80 \%$ benefited from natural resources by grazing their livestock and harvesting firewood and grasses. The majority $(90 \%)$ also suffered from livestock predation by Ethiopian wolves and common jackals (Canis aureus) and
\end{abstract}

Girma Eshete

girma.eshete@yahoo.com; genbere@cml.leidenuniv.nl

1 Conservation Biology Department, Institute of Environmental Sciences, University of Leiden, P.O. Box 9518, 2300 RA Leiden, The Netherlands

2 North Wollo Zone Environmental Protection Department, P.O. Box 461, Woldia, Ethiopia

3 Ethiopian Wolf Conservation Programme, P.O. Box 215, Robe, Bale, Ethiopia

4 College of Dryland Agriculture, Mekelle University, P.O. Box 231, Mekelle, Ethiopia

5 Wildlife Conservation Research Unit, Zoology Department, The Recanati-Kaplan Centre, University of Oxford, Tubney House, Abingdon OX13 5QL, UK

6 Frankfurt Zoological Society, P.O. Box 101426, Addis Ababa, Ethiopia crop raiding by geladas (Theropithecus gelada), birds, and rodents, yet more than half reported a positive attitudes toward Ethiopian wolves $(66 \%)$. People with positive attitudes tended to live close to the communal land, to own more livestock, and to be unaffected by conflict. Many also recognized the need to protect the Afroalpine habitats of Abune Yosef $(71 \%)$, and this attitude predominated among the literate, households that owned land, had smaller herds and were further away. We discussed how people's attitudes were modulated by human-wildlife conflicts and by the benefits derived from the access to natural resources in communal land, and the implications for the conservation of Afroalpine ecosystem and the flagship Ethiopian wolf.

Keywords Afroalpine ecosystem - Attitudes - Ethiopian highlands · Human-wildlife conflict · Natural resources

\section{Introduction}

People who perceive economic benefits and enjoy unrestricted access to natural resources are expected to be supportive of ecosystem conservation efforts (Kellert 1985; Brüner et al. 2001; Walpole and Goodwin 2001; Wang and Macdonald 2006). However, if the economic consequences of human-wildlife conflict for local poor households become unbearable, attitudes toward the conservation of biodiversity can change significantly (Oli et al. 1994; Treves and Karanth 2003; Naughton-Treves et al. 2005; Thirgood et al. 2005; Woodroffe et al. 2005; Treves 2007).

In the highlands of Ethiopia, the traditional livelihoods of the Amhara people combine subsistence agriculture with livestock rearing, complemented by access to natural resources in communal Afroalpine areas, including water, 
construction materials, firewood, and grazing land (Gebremedhin and Swinton 2002; Ashenafi et al. 2012). The Afroalpine ecosystems of Ethiopia have been used for millennia under unrestricted access by the surrounding communities (Ashenafi and Leader-Williams 2005; Ashenafi et al. 2012), but the rapidly growing human populations are posing new challenges. The intensification of farming and livestock grazing is resulting in environmental degradation and conflicts with wildlife across Ethiopia (Stephens et al. 2001; Bekalo and Bangay 2002; Yirga et al. 2012), with potential consequences for the conservation of Afroalpine ecosystems (Ashenafi and LeaderWilliams 2005; Marino 2003).

The Ethiopian highlands harbor an exceptionally diverse array of endemic species, among them the endangered Ethiopian wolf (Canis simensis) (Marino and Sillero-Zubiri 2011), gelada baboon (Theropithecus gelada), walia ibex (Capra walia), and several species of Rhizomyidae and Murinae rodents (Yalden and Largen 1992). The communal land in Mount Abune Yosef, North Wollo, is a good example of a high-biodiversity Afroalpine remnant which is critically important for the Amhara people and for Ethiopian wolves alike (Ash 2001; Marino 2003). In such a setting, people's attitudes toward conservation can have important consequences for the survival of wolves and other highland endemics, and for the long-term sustainability of traditional livelihoods. In particular, it is likely that communities develop negative attitudes toward wildlife conservation as a result of livestock predation or crop raiding (Sekhar 1998; Treves 2007; Marino 2003).

Previous studies of human-wildlife conflict in Ethiopia have been conducted within protected areas (Yihune et al. 2008, 2009; Tessema et al. 2010), where contacts between people and wildlife are largely restricted to the protected area boundaries. In densely populated highlands of Mount Abune Yosef in Wollo, however, these interactions will be more frequent and leading to conflicts due to livestock predation by common jackals (Canis aureus) and Ethiopian wolves (Marino 2003; Marino et al. 2010) and damage to barley fields caused by geladas and rodents (Dunbar 1998; Yihune et al. 2009; Kifle et al. 2013). If the economic consequences of these conflicts are significant for the local farmers, negative attitudes toward conservation might arise (Treves and Karanth 2003; Yirga et al. 2012; Winterbach et al. 2013). To test this hypothesis, we conducted semistructured interviews to generate qualitative and quantitative information about local livelihoods and wildlife conflicts in Mount Abune Yosef, taking into account the benefits derived from access to natural resources in communal land and how these affect people's attitudes and tolerance toward wildlife.

\section{Methods}

\section{Study Area}

Mount Abune Yosef (hereafter AY) is located in the Lasta district of North Wollo Zone, between $12^{\circ} 8^{\prime} 7^{\prime \prime} \mathrm{N}$ and $39^{\circ} 15^{\prime} 7^{\prime \prime} \mathrm{E}$ (Fig. 1). This isolated mountain reaches up to $4286 \mathrm{~m}$ a.s.l and contains approximately $50 \mathrm{~km}^{2}$ of suitable wolf habitats (Marino 2003; Saavedra 2009). The climate is moist and cold, with a wet season from June to October, and a dry season from November to May. The average annual rainfall is $2,000 \mathrm{~mm}$ and the mean annual temperature ranges between 7.5 and $11{ }^{\circ} \mathrm{C}$ (ESP 2001). The highlands of North Wollo are watersheds for three main river basins (Tekeze, Awash, and Blue Nile basins). The Amhara people settled in these highlands for millennia and still use traditional methods for farming and bring their livestock to graze in Afroalpine pastures. AY also has cultural value due to its scenery and the presence of endemic animals, which attract a growing number of visitors, and to centuries as an important religious site, with many churches and monasteries (Saavedra 2009). Mount Abune Yosef is located close to the holy city of Lalibela, one of Ethiopia's top tourist attractions. Taking advantage of this situation, a community-based tourism initiative was started a few years ago, with support of international NGOs.

The landscape is open and dominated by grasslands and heathlands, with steep slopes covered by rock and shallow soils, and valleys and depressions, with deep black soils, sustaining an important green biomass. The mosaic of Afroalpine vegetation types includes 'guassa' grasslands (Festuca spp.), giant lobelias (Lobelia rhyncopetalum), Euryops bushes locally known as 'chifra', 'kirshiba,' or 'charranfe', and remnant patches of Erica spp. forests. In AY, there are 43 species of mammals, including seven Ethiopian endemics, and 221 species of birds, of which 16 are endemic, making it the second most important bird area in the country (EWNHS 1996; Lepage 2006; Saavedra 2009).

\section{Data Collection and Analysis}

Pilot surveys were initially conducted in 16 households to gather background information and to test and adapt the questionnaire. Between October 2009 and April 2011, 120 households were interviewed, selected randomly from a list of 2014 households across eight villages in four Peasant Associations or 'kebeles' (the smallest local administration unit). The inhabitants of these villages visit the Afroalpine area of AY frequently to herd their livestock, to collect grass and firewood, or en route to local markets. It was 
Fig. 1 Map indicating areas of Afroalpine habitats in the Ethiopian highlands. Inset shows study area of Abune Yosef and adjacent Aboi Gara

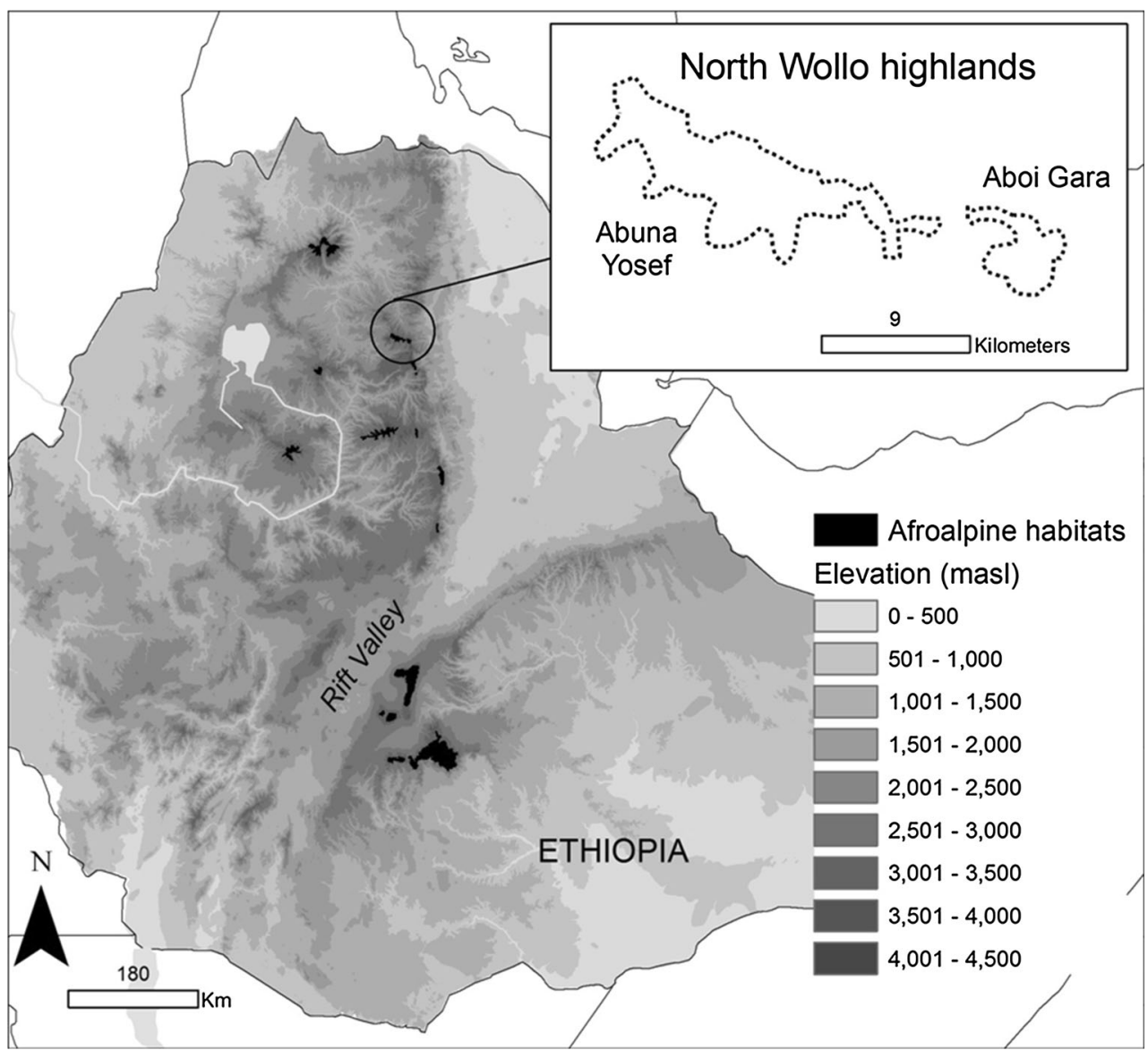

agreed that the information collated will only be used for the purpose of the study.

The questionnaire (Appendix) was designed to evaluate the local uses of Afroalpine natural resources for own consumption or to commercialize (e.g., firewood and grasses are sold for cash or exchanged in local markets to compensate for goods and services that are not locally unavailable or in deficit), the extent to which households were affected by predation, and their views regarding the need to protect Abune Yosef, and their attitudes toward wolf. We collected information about the heads of the household that is expected to influence attitudes, such as sex, marital status, family size, and educational status, together with others related to their livelihoods, expected to influence as well their degree of dependence upon additional Afroalpine resources, such as firewood and grasses, to compensate their livelihoods; namely whether the family owns land for agriculture ('own land'), the size of the plot ('land size'), whether they keep livestock ('herd size' as number of heads) and the grazing regime (months grazing at Mount Abune Yosef, and by season: dry and wet). Regarding conflicts with wildlife, the heads of households were asked about the type of conflict they are exposed to, namely livestock predation and crop raiding, and their frequencies and overall trends. Regarding attitudes, people were asked their view about the need to protect AY and their attitudes toward wolf and possibility that wolves and people co-exist in AY.

To calculate the financial benefits derived from the commercialization of natural resources, local market prices for the year 2010/11 were considered (load of firewood $=20$ Ethiopian birr; load of hay \& thatch grass $=50$ Ethiopian birr), and converted to USA dollars at an exchange rate of 1 US\$ $=10$ Ethiopian birr.

Descriptive statistics were used to describe local livelihoods, and cross tabulations and Chi square tests for categorical variables. We used logistic regressions to explore variations in peoples' attitudes, considered as binary response (e.g., yes/no answers: 0 for a negative response and 1 for positive). All analyses were conducted with the statistical packages SPSS (version 16) and SAS-JMP 5 software.

\section{Results}

\section{Socio-economic Characteristics and Resource Uses}

Regarding the socio-economic profile, most heads of household were married men and over half of them 
Table 1 Characteristics of the 120 households interviewed

\begin{tabular}{|c|c|c|c|c|c|}
\hline & \multicolumn{2}{|c|}{ Number } & \multicolumn{3}{|c|}{ Percentage of households (\%) } \\
\hline \multicolumn{6}{|l|}{ Sex } \\
\hline Male & \multicolumn{2}{|l|}{103} & \multicolumn{3}{|l|}{85.8} \\
\hline Female & \multicolumn{2}{|l|}{17} & \multicolumn{3}{|l|}{14.2} \\
\hline \multicolumn{6}{|l|}{ Marital status } \\
\hline Married & \multicolumn{2}{|l|}{103} & \multicolumn{3}{|l|}{85.8} \\
\hline Single & \multicolumn{2}{|l|}{17} & \multicolumn{3}{|l|}{14.2} \\
\hline \multicolumn{6}{|l|}{ Educational status } \\
\hline Illiterate & \multicolumn{2}{|l|}{63} & \multicolumn{3}{|l|}{52.5} \\
\hline Literate & \multicolumn{2}{|l|}{57} & \multicolumn{3}{|l|}{47.5} \\
\hline \multicolumn{6}{|l|}{ Own land } \\
\hline Yes & \multicolumn{2}{|l|}{104} & \multicolumn{3}{|l|}{86.7} \\
\hline No & \multicolumn{2}{|l|}{16} & \multicolumn{3}{|l|}{13.3} \\
\hline \multicolumn{6}{|c|}{ Affected by wildlife damage } \\
\hline Affected & \multicolumn{2}{|l|}{108} & \multicolumn{3}{|l|}{90.0} \\
\hline Not affected & \multicolumn{2}{|l|}{12} & \multicolumn{3}{|l|}{10.0} \\
\hline \multicolumn{6}{|l|}{ AY needs protection } \\
\hline Yes & \multicolumn{2}{|l|}{85} & 70.8 & & \\
\hline No & 35 & & 29.2 & & \\
\hline Responsible to protect & t AY & & & & \\
\hline Community & 96 & & 80 & & \\
\hline Government & 24 & & 20 & & \\
\hline Attitude toward Ethiop & pian wc & olf & & & \\
\hline Positive & 79 & & 65.8 & & \\
\hline Negative & 41 & & 34.2 & & \\
\hline Can co-exist with wol & lves & & & & \\
\hline Yes & 72 & & 60 & & \\
\hline No & 48 & & 40 & & \\
\hline Continuous variables & & Minimum & Maximum & Mean & SD \\
\hline Age & & 18 & 80 & 47.5 & 12.268 \\
\hline Family size & & 1 & 10 & 5.7 & 1.827 \\
\hline $\begin{array}{l}\text { Distance to Afroalpine } \\
\text { area }(\mathrm{km})\end{array}$ & & 2 & 15 & 7.72 & 4.199 \\
\hline $\begin{array}{l}\text { Herd size (number of } \\
\text { heads) }\end{array}$ & & 0 & 78 & 13.69 & 10.509 \\
\hline Land size (ha) & & 0 & 2.3 & 0.70 & 0.440 \\
\hline
\end{tabular}

illiterate. The majority owned land (average $0.7 \mathrm{ha}$ ) and a small herd of livestock (average 14 heads) (Table 1). Eighty percent of the households benefited economically from the use of natural resources, but this proportion varied across villages (Table 2) and over half $(61.7 \%$ ) used Afroalpine pastures to graze, for at least 9 months a year. All households located within $10 \mathrm{~km}$ of Mount Abune Yosef exploited some natural resource, but only a small proportion of the household located further away (Fig. 2). More landless households utilized natural resources in comparison with the households that owned agricultural land $\left(X^{2}=4.62\right.$, df $\left.=1, P<0.05\right)$.
Regarding the uses of natural resources, two thirds of the households reported collecting firewood, and many harvested thatching grass and hay (Table 3 ). Other natural resources were used as farming implements, construction materials, and medicinal plants, while tourism provided income to nearly one third of the households interviewed (Table 3).

The estimated financial benefit perceived by households was on average US\$ 92 per year, ranging from US\$ 5 from firewood sales to US\$ 300 from tourism revenues (tourist guiding, renting pack animals, and selling locally made items) (Table 4).

\section{Conflicts and Attitudes}

Nearly every household surveyed reported some form of wildlife damage, including livestock predation by Ethiopian wolves and common jackals, and crop damage by geladas, birds, and rodents (Table 5). Half of the households suffered both from livestock predation and crop raiding. The type of conflict differed across the villages $(P<0.01)$, while people in Enjafat and Latgie did not report wildlife-related damage, most households in Eyebelay, Korit, and Ybaro experienced both livestock predation and crop raiding (Table 5).

Most people believed that Ethiopian wolf numbers were decreasing in AY, alleging habitat loss, emigration, and competition with jackals as the causes $(43,26$, and $21 \%$ respectively). However, people reported seeing Ethiopian wolves on average $6.0 \pm 0.7$ times over the previous 12 months, compared with $13.0 \pm 1.7$ per year when they were asked over the last 5 years. Wolves were seen alone or in groups of up to 12 (average $4.2 \pm 0.2$ wolves), and most commonly in the early and late hours of the day (59\% at dawn and dusk, the rest at dawn only).

In spite of the relatively high frequency of livestock predation reported (affecting more than $90 \%$ of the households), more than half of people believed that people and Ethiopian wolves can co-exist in AY $(60 \%)$ and that they feel positively about them (66\%). This positive attitude was most common among households located close to Afroalpine areas, households with larger herds, and those less affected by wildlife predation (Table 6).

The majority of the respondents $(71 \%)$ perceived a need to protect Abune Yosef, and many preferred a community-based approach $(80 \%)$ over a government-led one. Interestingly, whether people used natural resources or not, whether they were affected by conflict or not, did not affect their perception. The households that considered some form of conservation were necessary tended to have literate heads, to own land, to have smaller herds, and to live further away from the Afroalpine area (Table 7). 
Table 2 Households per village that utilize natural resources from Abune Yosef

\begin{tabular}{lcc}
\hline Village & Households sampled & Benefit from natural resource uses \\
\hline Eyebelay & 17 & $13(76.5 \%)$ \\
Korit & 11 & $11(100 \%)$ \\
Abune Yoseph & 14 & $14(100 \%)$ \\
Latige & 10 & $10(100 \%)$ \\
Kassegne & 22 & $20(90.9 \%)$ \\
Enjafat & 13 & $4(30.8 \%)$ \\
Shegla & 11 & $9(81.8 \%)$ \\
Ybaro & 22 & $15(68.2 \%)$ \\
Total & 120 & $96(80 \%)$ \\
\hline
\end{tabular}

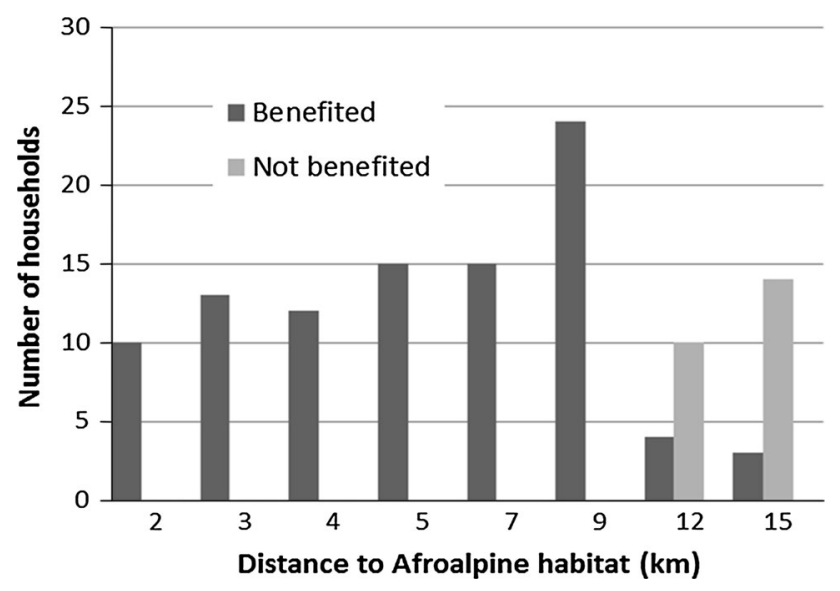

Fig. 2 Number of households that benefited from using natural resources at various distances from Abune Yosef

Table 3 Types of economic resources/services households obtained from Abune Yosef $(n=120)$

\begin{tabular}{lll}
\hline Resources & Number of households & $\%$ \\
\hline Firewood & 89 & 74.2 \\
Thatching grass & 76 & 63.3 \\
Hay grass & 66 & 55 \\
Tourism & 35 & 29.2 \\
Other & 92 & 76.7 \\
\hline
\end{tabular}

\section{Discussion}

Our study exemplifies how people's attitudes toward conservation and wildlife can be modulated by socio- economic characteristic and by conflicts with wildlife, in a case where open resource uses might conflict with the conservation of a charismatic endemic such as the Ethiopian wolf.

The local communities of Abune Yosef resembled other rural communities that engage in small-scale agriculture and livestock rearing, and which depend on biodiversity for their subsistence, for example, as a source of energy, building materials, drinking water, and products that can be bartered
Table 4 Economic benefits that households perceived from the use of natural resources in Abune Yosef

\begin{tabular}{lccccc}
\hline \multirow{2}{*}{ Resource } & \multicolumn{3}{l}{ Annual income (in Ethiopian birr) } & \multirow{2}{*}{$N$} \\
\cline { 2 - 4 } & Minimum & Maximum & Mean & SD & \\
\hline Firewood & 50 & 1050 & 324.8 & 272.8 & 89 \\
Thatching grass & 75 & 1500 & 477.4 & 362.8 & 76 \\
Hay grass & 120 & 1500 & 421.6 & 303.6 & 66 \\
Tourism & 100 & 3000 & 659.1 & 659.1 & 35 \\
\hline
\end{tabular}

and sold in local markets to access goods and services that are not locally available (Lewis et al. 1990; Newmark et al. 1993; Winterbach et al. 2013). Subsistence farmers around AY exploited diversified goods and environmental services from the Afroalpine ecosystem, as do communities in other Afroalpine areas of Ethiopia under some level of resource use management such as the Guassa Conservation Area (Ashenafi 2001) and the Simien Mountains National Park (Yihune et al. 2008). The communities of AY use Afroalpine pastures intensively, in many cases all year round, and depend on Afroalpine bushes as sources of firewood and to commercialize. This is the reality across rural Ethiopia, where most people depend on firewood for cooking and lighting, and on livestock as a form of financial insurance for times of necessity (Taddese 2001). The communities of AY also benefited financially by the commercialization of Festuca grasses and hay, used as fodder and for thatching and basket making (Ashenafi et al. 2012; Jacob et al. 2014), and other wild plants used for medicine and construction (Ashenafi 2001). Interestingly, a considerable proportion of the households benefited from tourism, revealing a significant financial impact of this touristic activities led by the local communities of AY. This adds to the evidence that tourism can be an important alternative source of income when developed as a community-based initiative, like in Guassa Community Conservation Area in Ethiopia (Ashenafi and Leader-Williams 2005) and in other African countries (Binns and Nel 2002; Hutton and Leader-Williams 2003; Lindsey et al. 2007; Hoole 2009; Mbaiwa and Stronza 
Table 5 Wildlife conflicts and percentage of households affected across villages

\begin{tabular}{lcccccc}
\hline Villages & Households sampled & With conflicts & $\%$ & Livestock predation only & Crop damage only & Both \\
\hline Eyebelay & 17 & 17 & 100 & $2(11.8 \%)$ & $3(17.6 \%)$ & $12(70.6 \%)$ \\
Korit & 11 & 11 & 100 & $3(27.3 \%)$ & $7(9.1 \%)$ & $3(21.4 \%)$ \\
Abune Yoseph & 14 & 13 & 93 & $6(42.9 \%)$ & 0 & $4(28.6 \%)$ \\
Latgie & 10 & 7 & 70 & $6(60 \%)$ & $1(4.5 \%)$ & $1(10 \%)$ \\
Kassegne & 22 & 20 & 91 & $9(40.9 \%)$ & $2(15.4 \%)$ & 0 \\
Enjafat & 13 & 9 & 69 & $3(23 \%)$ & $1(4.6 \%)$ & $6(30.8 \%)$ \\
Shegla & 11 & 9 & 82 & $3(27.3 \%)$ & $11(9.2 \%)$ & $6(54.5 \%)$ \\
Ybaro & 22 & 22 & 100 & $5(22.7 \%)$ & $60(50 \%)$ \\
Total & 120 & 108 & 90 & $37(30.8 \%)$ & & $0.7)$ \\
\hline
\end{tabular}

Table 6 Result of logistic regression explaining people's attitudes toward Ethiopian wolves $(1=$ positive. $0=$ negative $)$
Table 7 Result of logistic regression explaining people's perception of the need to protect the Afroalpine ecosystem $(1=$ there is a need to protect AY, $0=$ there is not)

\begin{tabular}{lrrrc}
\hline Explanatory variables & Estimate & Std Error & Chi Square & $P$ value \\
\hline Age & 0.005 & 0.024 & 0.044 & 0.838 \\
Marital status $(1=$ married) & -1.522 & 0.952 & 2.555 & 0.110 \\
Sex $(1$ if male) & 1.252 & 0.944 & 1.762 & 0.184 \\
Family size & 0.280 & 0.150 & 3.486 & 0.062 \\
Educational status $(1=$ literate) & 0.657 & 0.567 & 1.345 & 0.246 \\
Distance to Afroalpine area & -0.141 & 0.057 & 6.111 & 0.013 \\
Own land (1 if yes) & 0.154 & 0.801 & 0.037 & 0.848 \\
Herd size & 0.132 & 0.044 & 9.128 & 0.003 \\
Affected by wildlife damage $(1=$ not affected) & 2.193 & 0.742 & 8.744 & 0.003 \\
$R^{2}$ & 0.361 & & & \\
Correctly predicted percentage & 76.7 & & & \\
Observations & 120 & & & \\
\hline
\end{tabular}

\begin{tabular}{lcccc}
\hline Explanatory variables & Estimate & Std error & Chi square & $P$ value \\
\hline Age & -0.008 & 0.035 & 0.051 & 0.821 \\
Marital status $(1=$ married $)$ & 0.753 & 1.113 & 0.457 & 0.499 \\
Sex $(1=$ male $)$ & -0.833 & 1.110 & 0.562 & 0.453 \\
Family size & 0.223 & 0.175 & 1.611 & 0.204 \\
Educational status $(1=$ literate $)$ & 2.723 & 0.729 & 13.938 & 0.000 \\
Time living at AY & 0.017 & 0.024 & 0.516 & 0.473 \\
Distance to Afroalpine area & 0.248 & 0.096 & 6.601 & 0.010 \\
Own land (1 = yes) & 2.593 & 0.928 & 7.812 & 0.005 \\
Herd size & -0.087 & 0.037 & 5.615 & 0.018 \\
Firewood collection $(1=$ yes $)$ & 0.085 & 0.991 & 0.007 & 0.932 \\
Thatching grass collection $(1=$ yes) & 0.144 & 0.868 & 0.028 & 0.868 \\
Hay grass collection $(1=$ yes $)$ & 0.490 & 0.786 & 0.390 & 0.533 \\
Affected by wildlife damage $(1=$ not affected) & 0.625 & 0.873 & 0.513 & 0.474 \\
$R^{2}$ & 0.456 & & & \\
Correctly predicted percentage & 78.3 & & & \\
Observation & 120 & & & \\
\hline
\end{tabular}

2010). The estimated annual income derived from ecosystem goods and services provided by Mount Abune Yosef was US\$ 92 per household, a substantial economic contribution considering that the per capita average Gross National Income (GNI) of Ethiopians was US\$ 470 in 2013 (World Bank 2013). 
Consequently, most people considered the protection of natural resources positively, as their livelihoods will logically depend on the long-term persistence of these ecosystem services. Their attitudes, however, vary with socio-economic factors as in other rural areas of Africa, including the benefits derived from environmental goods and ecosystem services as well as the economic losses due to livestock predation (e.g., Romanach et al. 2007; Lagendijk and Gusset 2008; Dickman 2010). As expected, literacy was associated to people's perceptions of the need for conservation, a common pattern globally in North America (Kellert et al. 1996), South Africa (Lagendijk and Gusset 2008), and Uganda (Kugonza et al. 2009). Farmers that own land, and thus have a rural land certification provided by the local Land Administration Office, have right to use the farmland and surrounding natural resources, and thus more self-assured to benefit from conservation. In comparison, landless households exploit natural resources in unregulated ways, and might therefore feel threatened by conservation initiatives. This coincides with studies in Ethiopia and elsewhere showing that farmers that own land are more collaborative toward biodiversity conservation activities, than farmers using state owned or non-private land (Ellis 1996; Rahmato 2003; Teklu 2003; Romanach et al. 2007; Kugonza et al. 2009). Also the people living further away from the communal land and with smaller herds recognized more the need to protect Abune Yosef. One logical explanation is that the families living close to the communal land and with more heads of livestock are exerting competition upon them, so they perceive a greater urgency to protect the resources in the longer term and for the benefit of everyone. Among the other group of families, some might perceive conservation as a threat, as this entails restrictions to harvesting, traditional free grazing rights, and displacement.

With respect to the charismatic Ethiopian wolf, a flagship for the conservation of Afroalpine habitats, most people were positive about the wolves and believed on human-wolf co-existence. However, the challenges that livestock predation might have upon the local households economies were evident in the association between negative attitudes, smaller herds (i.e., households that will face a relatively high economic costs), and past exposition to livestock predation. Still, persecution and retaliatory killings were never reported as a cause for the perceived decline in the wolf population, and are not considered as threats to Ethiopian wolves elsewhere (Sillero-Zubiri and Macdonald 1997; Ashenafi et al. 2005; Marino et al. 2013). These contradicts with lessons from many other regions of the world, where predation by wild carnivores almost invariably generates negative attitudes among rural residents, and the ensued retaliation leading sometimes to severe population declines (e.g., Woodroffe 2000; Bauer 2003; Sogbohossou et al. 2011).

\section{Conservation Implications}

Our study describes the delicate equilibrium between the socio-economic needs of local people and the need to protect the Afroalpine ecosystem in AY, because local livelihoods not only depend on the income generated from natural resources but also suffered from wildlife-related costs. Careful management will be required if the dual goals of wildlife conservation and economic livelihood for communities are to be met (Linnell et al. 2001; Hutton and Leader-Williams 2003; Winterbach et al. 2013).

Although Ethiopian wolves are specialized rodent hunters, this study shows that in the heavily populated highlands of North Ethiopia they are common predators of livestock, possibly a reflection of dietary adjustments to less abundant rodent prey and high livestock availability (Sillero-Zubiri and Gottelli 1995; Marino et al. 2010). Still, due to their high charisma, conflicts have been kept on check. A reason for concern is the possibility of conflicts increasing, as human and livestock populations in rural Ethiopia continue to grow, threatening the sustainability of the local livelihoods and the emergence of retaliation (Dovie et al. 2006; Lagendijk and Gusset 2008). Understanding and mitigating the risk of livestock predation should be considered a priority for AY and other Ethiopian wolf populations. Results from the Simien Mountains National Park (Yihune et al. 2008) and other protected areas of Africa (e.g., in Cameroon by Van Bommel et al. 2007 and in Botswana by Schiess-Meier et al. 2007) indicate that predation will be highest close to the Afroalpine habitats where jackals and wolves live, and that predation will vary with the prevailing grazing regimes and guarding techniques.

Interventions designed to ensure access to natural resources while promoting long-term sustainability will contribute to maintain positive attitudes among people in AY (Dickman 2010; Winterbach et al. 2013), and continued willingness to co-existence with carnivores (Kellert et al. 1996; Hutton and Leader-Williams 2003; Bath et al. 2008; Dickman 2010). Considering that, demand for land in itself is a major threat to the conservation of Afroalpine ecosystems, opportunities for alternative incomes should always be promoted to ensure positive attitudes toward conservation among landless households in AY, of which tourism is a good example.

Acknowledgments The study was funded by the Ethiopian Wolf Conservation Programme, sponsored by Born Free, Wildlife Conservation Network and PTES, with support from the Frankfurt Zoological Society, Rufford Small Grant Foundations, and the North Wollo Zone Environmental Protection Department. Our thanks go to the communities of Abune Yosef which contributed their time and knowledge, and to the field assistants Desiew Gelaw and Dessale Melakie. 
Open Access This article is distributed under the terms of the Creative Commons Attribution 4.0 International License (http:// creativecommons.org/licenses/by/4.0/), which permits unrestricted use, distribution, and reproduction in any medium, provided you give appropriate credit to the original author(s) and the source, provide a link to the Creative Commons license, and indicate if changes were made.

\section{Appendix}

\section{Part-1 Introductory question}

Date of interview Enumerator's Name

1. Name of household head____ Wereda____ kebele____ Village

Age ___ Marital status 0 . Single 1. Married; Sex 0. Female 1. Male; Family size

Educational status: 0. Illiterate 1. Literate; How long have you lived at your current area?

How far is your residence from Mount Abune Yosef (in km) Do you own land? 0. No 1. Yes

If yes, what is the size of your land holding in hactare?

How many livestock do you own at this time? Cattle sheep goats mules horses donkeys

\section{Part-2 Economic benefit from Mount Abune Yosef}

1. For how many months do you graze at Mount AbuneYosef (AY)? During dry season during wet season

2. Does AY bring economic benefit to your household? 0. No 1. Yes

3. Based on question 2, which type of benefit?

a. Firewood 0. No 1 . Yes if yes, how many loads of fire wood do you collect and how many of it did you sale in the last 12 months? Market price of firewood per load in Ethiopian Birr (ETB)

b. Thatching grass 0. No 1 . Yes if yes, how many loads of thatching grass do you cut and how many of it did you sale in the last 12 months? Market price of thatching grass per load in ETB

c. Hay grass 0. No 1 . Yes if yes, how many loads of hay do you harvest and how many of it did you sale in the last 12 months? Market price of hay per load in ETB

d. Did you get income from tourists visited AY in the last 12 months? 0 . No 1. Yes if yes, in what type of tourist activity did you involve? How much ETB did you make from tourism in the last 12 months?

e. Other benefits you get from AY and their estimated income

4. What estimated average benefits have you made in ETB from AY in a year? 


\section{Part-3 Attitudes towards Afroalpine Ecosystem, Ethiopian wolf and Wildlife conflict}

5. Is there a need to protect the natural resources of AY Afroalpine ecosystem? 0. No 1. Yes

6. Who do you think to manage the protection of AY Afroalpine ecosystem? 0. Government 1. Local community

7. List wildlife that you know at AY?

8. Did you face damage because of wildlife in AY? 0. No 1. Yes

9. If yes, to question number 8 , what is the damage you face from wildlife?

10. Which wild animals are the most problematic in livestock predation at AY?

11. What is the trend of livestock predation by wildlife? 0 . Decreasing 1 . Increasing

12. Which wild animals are most problematic in terms of crop raiding?

13. What is the tendency of crop damage by wildlife? 0 . Decreasing 1 . Increasing

14. Have you personally seen Ethiopian wolves (EW) in AY? 0. No 1. Yes

15. How many times have you seen EW in the last 12 month's and past 5 years?

16. What times of the day you are more likely to see EW?

17. What is the largest group of EW you have seen in AY?

18. What do you think about the number of EW in AY? 0. Decreasing 1. Increasing Explain your reasons why you think increasing/ decreasing number of wolves in AY

19. In your opinion, can wolves live harmoniously in the same area with people? 0. No 1. Yes

20. What is your attitude towards wolves? 0 . Negative 1 . Positive

\section{References}

Ash NJ (2001) Expansion of Ethiopian wolf conservation to northern Ethiopia. Canid News 4(1):2

Ashenafi ZT (2001) Common property resource management of an Afroalpine habitat supporting a population of the critically endangered Ethiopian wolf Canis simensis. Dissertation, University of Kent

Ashenafi ZT, Leader-Williams N (2005) Indigenous common property resource management in the Central Highlands of Ethiopia. Hum Ecol 33:539-563
Ashenafi ZT, Coulson T, Sillero-Zubiri C, Leader-Williams N (2005) Behaviour and ecology of the Ethiopian wolf (Canis simensis) in a human-dominated landscape outside protected areas. Anim Conserv 8:113-121

Ashenafi ZT, Leader-Williams N, Coulson T (2012) Consequences of human land use for an Afro-alpine ecological community in Ethiopia. Conserv Soc 10:209-216

Bath A, Olszanska A, Okarma H (2008) From a human dimensions perspective, the unknown large carnivore: public attitudes toward Eurasian lynx in Poland. Hum Dimens Wildl 13:31-46 
Bauer H (2003) Local perceptions of Waza National Park northern Cameroon. Environ Conserv 30:175-181

Bekalo S, Bangay C (2002) Towards effective environmental education in Ethiopia: problems and prospects in responding to the environment-poverty challenge. Int J Educ Dev 22:35-46

Binns T, Nel E (2002) Tourism as a local development strategy in South Africa. Geogr J 168:235-247

Brüner AG, Gullison RE, da Fonseca GA (2001) Effectiveness of parks in protecting tropical biodiversity. Science 291:125-128

Dickman AJ (2010) Complexities of conflict: the importance of considering social factors for effectively resolving humanwildlife conflict. Anim Conserv 13:458-466

Dovie DB, Shackleton CM, Witkowski E (2006) Valuation of communal area livestock benefits, rural livelihoods and related policy issues. Land Use Policy 23:260-271

Dunbar RIM (1998) Impact of global warming on the distribution and survival of the gelada baboon: a modeling approach. Glob Change Biol 4:293-304

Ellis F (1993) Peasant economics: farm households and agrarian development, 2nd edn. Cambridge University Press, Cambridge

ESP (2001) The Federal Democratic Republic of Ethiopia Ministry of Agriculture, The resources of North Wollo Zone (ANRS), Addis Ababa

EWNHS (1996) Important bird areas of Ethiopia. Commercial Printing Press, Addis Ababa

Gebremedhin B, Swinton S (2002) Sustainable management of private and communal lands in the northern Ethiopia. Michigan State University, Michigan

Hoole AF (2009) Place-power-prognosis: community-based conservation, partnerships, and ecotourism enterprises in Namibia. Int J Commons 4:78-99

Hutton JM, Leader-Williams N (2003) Sustainable use and incentivedriven conservation: realigning human and conservation interests. Oryx 37:215-226

Jacob M, Frankl A, Beeckman H, Mesfin G, Hendrickx M, Guyassa E, Nyssen J (2014) North Ethiopian Afro-alpine tree line dynamics and forest-cover change since the early 20th century. Land Degrad Dev. doi:10.1002/ldr.2320

Kellert SR (1985) Public perceptions of predators, particularly the wolf and coyote. Biol Conserv 31:167-189

Kellert SR, Black M, Rush CR, Bath AJ (1996) Human culture and large carnivore conservation in North America. Conserv Biol 10:977-990

Kifle Z, Belay G, Bekele A (2013) Population size, group composition and behavioral ecology of geladas (Theropithecus gelada) and human-gelada conflict in Wonchit Valley, Ethiopia. Pak J Biol Sci 16:1248-1259

Kugonza A, Buyinza M, Byakagaba P (2009) Linking local communities livelihoods and forest conservation in Masindi District, North Western Uganda. Res J Appl Sci 4:10-16

Lagendijk DD, Gusset M (2008) Human-carnivore coexistence on communal land bordering the Greater Kruger Area, South Africa. Environ Manag 42:971-976

Lepage D (2006) Avibase. Bird checklists of the world. Birdlife International. http://www.bsceoc.org/avibase/. Accessed Dec 2009

Lewis D, Kaweche GB, Mwenya A (1990) Wildlife conservation outside protected areas lessons from an experiment in Zambia. Conserv Biol 4:171-180

Lindsey P, Roulet P, Romanach S (2007) Economic and conservation significance of the trophy hunting industry in sub-Saharan Africa. Biol Conserv 134:455-469

Linnell JD, Swenson JE, Anderson R (2001) Predators and people: conservation of large carnivores is possible at high human densities if management policy is favorable. Anim Conserv 4:345-349
Sillero-Zubiri C, Macdonald D, IUCN/SSC (eds.) (1997) The Ethiopian wolf-status survey and conservation action plan. IUCN, Gland, Switzerland

Marino J (2003) Threatened Ethiopian wolves persist in small isolated Afroalpine enclaves. Oryx 37:62-71

Marino J, Sillero-Zubiri C (2011) Canis simensis. IUCN Red List of Threatened Species Version 2011. http://www.iucnredlist.org

Marino J, Mitchell R, Johnson PJ (2010) Dietary specialization and climatic-linked variations in extant populations of Ethiopian wolves. Afr J Ecol 48:517-525

Marino J, Sillero-Zubiri C, Gottelli D, Johnson PJ, Macdonald DW (2013) The fall and rise of Ethiopian wolves: lessons for conservation of long-lived, social predators. Anim Conserv 16:621-632

Mbaiwa JE, Stronza AL (2010) The effects of tourism development on rural livelihoods in the Okavango Delta, Botswana. J Sustain Tour 18:635-656

Naughton-treves L, Holland MB, Brandon K (2005) The role of protected areas in conserving biodiversity and sustaining local livelihoods. Annu Rev Environ Resour 30:219-252

Newmark WD, Leonard NL, Sariko HI, Gamassa DG (1993) Conservation attitudes of local people living adjacent to five protected areas in Tanzania. Biol Conserv 63:177-183

Oli MK, Taylor IR, Rogers ME (1994) Snow leopard Panthera uncia predation of livestock: An assessment of local perceptions in the Annapurna Conservation Area, Nepal. Biol Conserv 68:63-68

Rahmato D (2003) Resettlement in Ethiopia: The Tragedy of Population Relocation in the 1980s. FSS Discussion Paper No. 11, Forum for Social Studies, Addis Ababa

Romanach SS, Lindsey PA, Woodroffe R (2007) Determinants of attitudes towards predators in central Kenya and suggestions for increasing tolerance in livestock dominated landscapes. Oryx 41:185

Saavedra D (2009) The Abune Yosef massif birds and mammals of a hidden jewel of Ethiopia, Universitat De Barcellona, center de recursos biodiversitat animal

Schiess-Meier M, Ramsauer S, Gabanapelo T, König B (2007) Livestock predation-insights from problem animal control registers in Botswana. J Wildl Manag 71:1267-1274

Sekhar NU (1998) Crop and livestock depredation caused by wild animals in protected areas: the case of Sariska Tiger Reserve, Rajasthan, India. Environ Conserv 25:160-171

Sillero-Zubiri C, Gottelli D (1995) Diet and feeding behaviour of Ethiopian wolves (Canis simensis). J Mammal 76:531-541

Sogbohossou EA, De Iongh H, Sinsin B, De Snoo G, Funston PJ (2011) Human-carnivore conflict around Pendjari Biosphere Reserve, northern Benin. Oryx 45:569-578

Stephens PA, Candy AS, Sillero-Zubiri C, Leader-Williams N (2001) Impact of livestock and settlement on the large mammalian wildlife of Bale Mountains National Park, southern Ethiopia. Biol Conserv 100:307-322

Taddese G (2001) Land degradation: a challenge to Ethiopia. Environ Manag 27:815-824

Teklu T (2003) Rural lands and evolving tenure arrangements in Ethiopia: Issues, evidence and policies. FSS discussion paper No.10, Forum for social studies, Addis Ababa

Tessema ME, Ashenafi ZT, Lilieholm RJ, Leader-Williams N (2010) Community attitudes towards wildlife and protected areas in Ethiopia. Soc Nat Resour 23:489-506

Thirgood S, Woodroffe R, Rabinowitz A (2005) The impact of human-wildlife conflict on human lives and livelihoods. Conserv Biol Ser 9:13

Treves A (2007) Balancing the needs of people and wildlife, when wildlife damage crops and prey on livestock. Tenure $\mathrm{Br} 7: 1-10$ 
Treves A, Karanth U (2003) Human-carnivore conflict and perspectives on carnivore management worldwide. Conserv Biol 17:1491-1499

Van Bommel L, Bij de Vaate M, De Boer W, De Iongh H (2007) Factors affecting livestock predation by lions in Cameroon. Afr J Ecol 45:490-498

Walpole MJ, Goodwin HJ (2001) Local attitudes towards conservation and tourism around Komodo National Park, Indonesia. Environ Conserv 28:160-166

Wang SW, Macdonald D (2006) Livestock predation by carnivores in Jigme Singye Wangchuck National Park, Bhutan. Biol Conserv 129:558-565

Winterbach H, Winterbach C, Somers M, Hayward M (2013) Key factors and related principles in the conservation of large African carnivores. Mamm Rev 43:89-110

Woodroffe R (2000) Predators and people: using human densities to interpret declines of large carnivores. Anim Conserv 3:165-173
Woodroffe R, Thirgood S, Rabinowitz A (2005) The impact of human-wildlife conflict on natural systems. Conserv Biol Ser 9:1

World Bank (2013) Ethiopian Overview Country report. http://www. worldbank.org/en/ethiopia/overview. Accessed Nov 2014

Yalden DW, Largen MJ (1992) The endemic mammals of Ethiopia. Mamm Rev 22:115-150

Yihune M, Bekele A, Ashenafi ZT (2008) Human-Ethiopian wolf conflict in and around the Simien Mountains National Park, Ethiopia. Int J Ecol Environ Sci 34:149-155

Yihune M, Bekele A, Ashenafi ZT (2009) Human-gelada baboon conflict in and around the Simien Mountains National Park, Ethiopia. Afr J Ecol 47:276-282

Yirga G, De Iongh H, Leirs H, Gebrehiwot K, Berhe G, Asmelash T, Gebrehiwot K, Bauer H (2012) The ecology of large carnivores in the highlands of northern Ethiopia. Afri J Ecol 51:78-86 